\title{
Commercializing innovations from agricultural research in Northern Ghana and farmers' willingness to pay
}

\author{
Alhassan, N. Jinbaani ${ }^{1}$, Samuel, A. Donkoh ${ }^{2}$, Franklin, N. Mabe ${ }^{2}$ and Isaac Gershon Kodwo \\ Ansah $^{2 \star}$ \\ ${ }^{1}$ Savannah Agricultural Research Institute, P. O. Box 52, Tamale, Ghana. \\ ${ }^{2}$ Department of Agricultural and Resource Economics, University for Development Studies, Faculty of Agribusiness and \\ Communication Sciences, P. O. Box TL1882, Nyankpala Campus, Tamale, Ghana.
}

Received 5 January 2016; Accepted 25 February, 2016

\begin{abstract}
The study used contingent valuation to solicit monetary values from researchers and farmers on how much they were willing to sell and buy agricultural innovations from research respectively. A probit model was then employed to identify the determinants of researchers' willingness to sell innovations from research. Furthermore, a multivariate (MV) probit model was estimated to explain key determinants of farmers' willingness to pay (WTP) for such innovations (technologies). Multi-stage sampling methods were used to obtain data from $\mathbf{3 6 0}$ farmers and 51 research scientists for the study. Though majority of farmers were willing to pay for agricultural innovations, the amounts they were prepared to pay (average of GHC6.00), were far less than what the researchers wanted them to pay (average of GHC50.00). The probability of a researcher accepting payment for innovations from research was high for the following categories of researchers: younger researchers; researchers who were members of professional bodies; and researchers with a high number of publications. The following categories of farmers also had a higher probability of paying for research output: younger farmers; farmers with high level of formal education; native farmers; farmers who had contacts with extension staff; and farmers with high income from their previous farming and non-farming activities. Considering the wide disparity between researchers' WTA payment for innovations and farmers' WTP, commercialization of research is possible but cannot be run on full cost-recovery. Government should therefore set up a statutory fund dedicated to agricultural research as a way of subsidizing agricultural innovations.
\end{abstract}

Key words: Agricultural innovations, contingent valuation, multivariate probit model, willingness to pay, willingness to accept, probit model.

\section{INTRODUCTION}

Technology transfer and adoption have been identified as key to improving agricultural productivity, but funding of research and technology dissemination has also been a challenge to public research institutions and universities.
It is against this background that research commercialization is strongly advocated by policy makers. To policy makers, research commercialization would improve private sector's access to research results from public

*Corresponding author. E-mail: agershon@uds.edu.gh.

Authors agree that this article remain permanently open access under the terms of the Creative Commons Attribution License 4.0 International License 
institutions, generate more funds for research and development, increase national competitiveness, optimize the return on public research funding and usage of innovations as well as help public research institutions overcome their budgetary constraints (Karlsson, 2004; Ali et al., 2008).

Ghana has therefore taken steps to operationalize research commercialization and to ensure that there is benefit not only to the end users of research products but also to researchers. This has led to the enactment of laws on Intellectual Property (IP) rights. These IP laws include the Patent Act, 2003 (Act, 657), the Copyright Act, 2005 (Act 690), Trade Marks Act, 2004, (Act 664), Industrial Designs Act, 2003 (Act 660) and Geographical Indications Act, 2003 (Act 659) (Constitution of the Republic of Ghana, 1996). Ghana is also a member of the World Intellectual Property Organization (WIPO). Additional laws have been enacted as part of efforts aimed at operationalizing commercialization of some research innovations, especially improved seed, which seems to be the focus of the Ghana government for now. Notable among them is the enactment of a new law called the Plants and Fertilizer Act 2010, (and a Plant Breeder's bill is currently before Ghana's Parliament awaiting to be passed into law). These policy regulations and laws are necessary but not sufficient condition for improving Ghana's agricultural productivity. For example, supply of good seed is not an end in itself. It is only part of a number of factors of crop management that contribute to farm productivity. While it is important to examine the seed supply side as the various laws and regulations seek to do, the demand side which is most critical is often overlooked (Tripp and Mensah-Bonsu, 2013). Also, what is often over looked is the demand for the other components of crop management necessary for farm productivity: soil fertility management, field crop protection and post-harvest techniques, in a research commercialization regime.

Presently, there is limited empirical research on the level of commercialization of innovations from agricultural research and the possible determinants of farmers ' willingness to pay for the innovations. It is also not clear how much researchers will be willing to sell their innovations upon commercialization and how much farmers too will be willing to buy such innovations from researchers. Information on these is crucial in making an informed opinion on whether commercializing innovations from research is a viable and sustainable alternative to public funding of agricultural research in Ghana or not. This study sought to look at, ex-ante, researchers' willingness to accept payment for their research output and farmers' willingness to pay for these innovations.

\section{LITERATURE REVIEW}

Innovation is the creation of new, better or more effective processes, technology or ideas for the production of goods and services. However, innovation in itself is not enough. It is useful when it is adopted and used by markets, governments and society (Bechdol, 2012). Technology is usually defined by economists as a stock of available techniques or a state of knowledge concerning a relationship between inputs and outputs (Colman and Young, 1989). Technology development creates opportunities, benefits and efficiency gains for farmers resulting in competitive utilization of factors of production (Gurel, 1998).

Rogers (1995) defined a technology as an instrumental action that reduces the uncertainty in the cause-effect relationships involved in achieving a desired outcome. A technology usually has two components, the hardware and the software aspects. The hardware aspect consists of the tool that embodies a material or physical object while the software component is the information-base for the tool. Rogers stated that the social embedding of the software component of a technology is usually less visible than its machinery or equipment and so technology is often understood in its hardware terms, especially agricultural technologies (Rogers, 1995). Perkmann et al. (2013) defined commercialization as intellectual property creation and academic entrepreneurship. Markmann et al. (2008) contended that commercialization is a key example for generating academic impact because it constitutes immediate, measurable market acceptance for outputs of academic research. Commercialization represents one important way for academic research to contribute to the economy and society (Salter and Martin, 2001).

Many factors have been hypothesized as having some influence on the commercialization of innovations from research in a number of studies. These factors are well explained and categorized into individual, organizational, socio-cultural, statutory and economic factors (Fakur, 2007; Radfar et al. 2009; Mohammadi et al., 2009; Nemati and Jamshidi, 2007; Bandaryan, 2009).

\section{MATERIALS AND METHODS}

\section{Theoretical framework}

The conceptual base for this study lies in the need for private participation in funding agricultural research through commercialization of innovations from research. Specifically, the need for agricultural research to move from "business-as-usual" to resultsoriented and demand-driven academic discipline yielding financial rewards to scientists for their ingenuity and hard work as well as increased income to farmers through increased productivity as a result of adoption of innovations from research.

According to Holden and Shiferaw (2002) and Ulimwengu and Sanyal (2011), willingness to pay is modelled as a sacrifice of current income in order to sustain or increase agricultural productivity in the future.

Therefore, expenditure function is used to estimate WTP for improvement in the quality of a resource. The minimum expenditure level (e) required to achieve the initial utility level is given by an expenditure function as 


$$
e=e\left(p, E U_{0}, F_{0}\right)
$$

where $\mathrm{p}$ is the vector of prices, $E U_{0}$ is the current expected utility level, and $F_{0}$ is the set of old agricultural services and farm characteristics. This means the amount of money a farmer spends in acquiring improved agricultural innovations is a function of prices, expected utility as well as agricultural services and farm characteristics. It follows that the willingness to pay in order to sustain current level of farm productivity is given by

$$
W T P=e\left(p, E U_{0}, F_{0}\right)-e\left(p, E U_{0}, F_{1}\right)
$$

Where WTP is the amount at which the household feels indifferent between the expected marginal utility under the old set of technologies and the discounted expected marginal utility of the change in future incomes as a result of the new set of agricultural technologies; $F_{1}$ is the new set of agricultural services and farm characteristics. Researchers' willingness to commercialize innovations can be analysed using willingness to accept (WTA) as proxy. WTA measures how much a respondent is willing to accept as compensation for a loss of a good or service. Contingent valuation tends to quantify the value consumers assign to products using a hypothetical purchasing situation in which they have to answer how much money they would be willing to pay for a given product, or if they would be willing to pay for a certain price premium (Carmona-Torres and Calatrava-Requena, 2006).

\section{The probit model}

The response variable, researchers' willingness to accept payment for agricultural technologies, is qualitative in nature. The appropriate model is a discrete choice model such as the probit model (Gujurati, 2004). Following Gujarati (2004), to motivate the probability model, the decision of the $i^{\text {th }}$ researcher's willingness to accept payment for agricultural technology or not depends on an unobservable utility index I. This utility index is a latent variable which is determined by a number of explanatory variables. The index, $l_{i}$ is expressed as

$I_{i}=\beta_{1}+\beta_{2} X_{i}$

In establishing the relation between the unobservable utility index and the actual decision making on willingness to accept payment, a threshold level of the utility index is assumed, say $I_{i}^{*}$.

if $I_{i}>I_{i}^{*}, I=1$

if $I_{i} \leq I_{i}^{*} \mathrm{I}=0$

Given the assumption of normality, the probability that $I_{i}^{*}$ is less than or equal to $I_{i}$ can be computed from the standardized normal cumulative density function (CDF) as

$$
\begin{aligned}
P_{i}=P(Y=1 \mid X) & =P\left(I_{i}^{*} \leq I_{i}\right)=P\left(Z_{i} \leq \beta_{1}+\beta_{2} X_{i}, \ldots \ldots \ldots \beta_{n}\right) \\
& =F\left(\beta_{1}+\beta_{2} X_{i} \ldots \ldots \ldots \ldots \beta_{n} X_{n}\right)
\end{aligned}
$$

where $P(Y=1 \mid X)$ means the probability that an event occurs given the values of the explanatory variables and where $Z_{i}$ is the standardized normal value, i.e. $Z \sim N\left(O, \sigma^{2}\right)$. $\mathrm{F}$ is the standard normal CDF. Taking the inverse of the CDF gives

$I_{i}=F^{-1}\left(I_{i}\right)=F^{-1}\left(P_{i}\right)=\beta_{1}+\beta_{2} X_{i} \ldots \ldots \ldots \ldots \beta_{n} X_{n}$

where $F^{-1}$ is the inverse of the normal CDF.

In the case of farmers' willingness to pay, running a separate estimation for determining willingness to pay for different agricultural technologies is likely to yield biased estimates especially in a situation where the willingness to pay for one agricultural technology significantly correlates with the willingness to pay for other technologies (Ulimwengu and Sanyal, 2011). Therefore, in this study, while a probit model is used to determine the factors influencing researchers' willingness to accept payment, a multivariate probit model is used to estimate farmers' willingness to pay for different agricultural technologies.Following Capellari and Jenkins (2003), the multivariate probit is given as

$y_{i m}^{*}=\beta X_{i m}+\varepsilon_{i m}, m=1 \ldots \ldots \ldots \ldots \ldots \ldots \ldots \ldots . \mathrm{M}$

$y_{i m}=1$ if $y_{i m}^{*}>0$ and 0 otherwise, $\mathcal{E}_{i m}, m=1 \ldots \ldots \ldots \ldots . . . . M$ are error terms distributed as multivariate normal, each with a mean of zero, and variance-covariance matrix $\mathrm{V}$, where $\mathrm{V}$ has values of 1 on the leading diagonal and correlations. Capellari and Jenkins (2003) noted that the model has a structure similar to that of a seemingly unrelated regression (SUR) model, except that the dependent variables are dichotomous. The Geweke-Hajiuassiliou-Keane (GHK) smooth recursive conditioning simulator is used for estimating the multivariate probit model (Borsch-Supan and Hajivassiliou, 1993; Capellari and Jenkins, 2003).

If $y_{j}^{i}$ denote farmer is binary response outcome associated with each $j$ type of agricultural technology, for $j=1$ such that $y_{j}^{i}$ is 1 if farmer $I$ is willing to pay for agricultural technology $j$ and 0 otherwise. Ulimwengu and Sanyal (2011) showed that the multivariate probit model can be specified as a linear combination of deterministic and stochastic component:

$y_{j}^{i}=x^{\prime} \beta_{j}+\varepsilon_{j}$

Where $x=\left(1, x, \ldots \ldots \ldots \ldots ., x_{p}\right)$ is a vector of $p$ covariates, which do not differ and $\boldsymbol{\beta}_{\mathrm{j}}=\left(\boldsymbol{\beta}_{\mathrm{jo}}, \boldsymbol{\beta}_{\mathrm{jp}}\right)$ is corresponding vector of parameters to be estimated. The error term $\varepsilon_{\mathrm{j}}$ consists of those unobservable factors affecting the marginal probability of WTP for a type of $\mathrm{j}$ agricultural technology. They added that each $\mathcal{E}_{\mathrm{j}}$ is drawn from a $\mathrm{J}$-variate normal distribution with zero conditional mean and variance normalized to unity (for parameter identification): $\mathcal{E} \sim \mathrm{N}(\mathrm{O}$, $\Sigma$ ) with the variance covariance matrix given by:

$\Sigma=\left[\begin{array}{ccc}1 & P_{12} & \ldots \ldots P_{1 j} \\ P_{21} & 1 & \ldots \ldots P_{2 j} \\ P_{j 1} & P_{j 2} & \ldots \ldots .1\end{array}\right]$

The off-diagonal elements in the covariate matrix $\mathrm{P}_{\mathrm{sj}}$ represent the unobserved correlation between the stochastic component of the $s^{\text {th }}$ and the $\mathrm{j}^{\text {th }}$ types of the agricultural technology (innovations).

\section{Empirical specification of the probit model}

Following the theoretical model explained earlier the empirical model to researchers' WTA payment for their innovations is as follows:

$Y_{i}=\beta_{0}+\beta_{1}$ Age $_{i}+\beta_{2}$ Mem $_{i}+\beta_{3}$ Exp $_{i}+\beta_{4}$ No.Pub $_{i}+\beta_{5}$ Non.Pro. $_{i}+$

$\beta_{6}$ Dep.Sal ${ }_{i}+\beta_{7}$ Nec.Pub $i+\varepsilon_{i}$

Where $Y_{i}=$ Researchers' WTA payment for his innovations; $\varepsilon_{i}=$ Sample Error Term

The multivariate probit model for modelling the determinants of farmers' WTP for innovations from research is

$Y_{j i}^{*}=\sum_{m=1}^{m=7} X_{m i} \beta_{m j}+\varepsilon_{j i}$ 
Table 1. Definition of researchers' socio-economic variables.

\begin{tabular}{|c|c|c|c|}
\hline Variable & Definition & Measurement & A Priori expectation \\
\hline Age & Age of respondent & Age of a researcher, measured in years. & Positive \\
\hline Mem & Membership to a professional body & $\begin{array}{l}\text { Dummy; } 1 \text { if a researcher belonged to a } \\
\text { professional body; } 0 \text { otherwise }\end{array}$ & Positive \\
\hline Exp & Years of Experience & $\begin{array}{l}\text { Number of years a respondent had been a } \\
\text { researcher }\end{array}$ & Positive \\
\hline No.Pub & Number of publications & $\begin{array}{l}\text { Number of research published papers a respondent } \\
\text { had }\end{array}$ & Positive \\
\hline Non.Pro & $\begin{array}{l}\text { Researchers' perception regarding the } \\
\text { non-profit nature of extension delivery } \\
\text { (technology transfer) }\end{array}$ & $\begin{array}{l}\text { Dummy; } 1 \text { if a researcher perceived that the non- } \\
\text { profit nature of extension delivery negatively } \\
\text { affected research commercialization; } 0 \text { otherwise }\end{array}$ & Negative \\
\hline Dep.Sal & $\begin{array}{l}\text { Dependence on stated regular source } \\
\text { of salary (Government subvention) }\end{array}$ & $\begin{array}{l}\text { Dummy; } 1 \text { if regular source of salary will affect } \\
\text { commercialization positively; } 0 \text { otherwise }\end{array}$ & Negative \\
\hline Nec.Pub & $\begin{array}{l}\text { Necessity to publish in order to be } \\
\text { promoted }\end{array}$ & $\begin{array}{l}\text { Dummy; } 1 \text { if a researcher agreed that the necessity } \\
\text { to publish in order to be promoted could increase } \\
\text { research commercialization; } 0 \text { otherwise }\end{array}$ & Positive/ Negative \\
\hline
\end{tabular}

where $\mathrm{j}$ is the type of agricultural technology, $X_{m=} X_{1}, X_{2}, X_{3}$, $X_{4}, X_{5}, X_{6}, X_{7}$ and $X_{8}$ are socio-economic factors influencing the dependent variable, farmers' WTP for innovations from research. $Y_{j}^{*}=Y_{1}^{*}, Y_{2}^{*}, \ldots, Y_{7}^{*}$

denotes farmers' willingness to pay for improved seed, soil fertility improvement techniques, weed and pest control methods, safe use of agro-chemicals, crop disease identification and control measures, farm management and record keeping and post-harvest techniques, respectively. Also $\beta_{m}=\beta_{1}, \beta_{2}, \ldots, \beta_{8}$ are parameters to be estimated and $\varepsilon_{j}=\varepsilon_{1}, \varepsilon_{2}, \ldots, \varepsilon_{i 8}$ are error terms attributed as multivariate normal. The descriptions of the variables as well as their priori expectations are indicated in Tables 1 and 2.

\section{Study area, sampling procedure and data collection}

The study was carried out in Northern Ghana, which comprises the Upper West, Upper East and Northern Regions. A total of six districts were randomly sampled for the study; two from each of the three northern regions of Ghana. Six communities were then selected from each district and ten farmers from each of the selected communities through simple random sampling technique. In total, three hundred and sixty farmers were interviewed with the use of semi structured questionnaires. Fifty one researchers were also randomly selected and interviewed from two purposively selected institutions: University for Development Studies (U.D.S.) and Savannah Agricultural Research Institute (SARI) based on their specialization in the following areas of agricultural technology: improved seed varieties (early maturing, high yielding, droughtresistant, striga-resistant, improved palatability), recommended seed and fertilizer rates, recommended planting distances, soil fertility management practices, pest and disease control, postharvest techniques and improved soil and water conservation practices. Both institutions also have their mandates covering the three regions of northern Ghana. The main source of data for the study was primary, which was collected using semi-structured questionnaires. The questionnaires were administered to both farmers and researchers. Each questionnaire contained a hypothetical market situation.

\section{RESULTS AND DISCUSSIONS}

\section{Descriptive analysis of willingness to sell and pay for innovations from research}

The main objective of this study was to assess researchers' willingness to sell innovations from research and farmers' willingness to pay for such innovations. The study revealed that $59 \%$ of researchers were willing to sell their innovations or provide extension service to farmers for a fee. The respondents who expressed their willingness to sell innovations from research gave various reasons for their answer. The highest percentage of respondents $(43.3 \%)$ considered private participation as critical in sustaining funding for agricultural research.

Similarly, $26.7 \%$ thought that farmers would value research innovations more if they paid for it. About 16.7\% of respondents saw service charges from the sale of innovations as a source of motivation and incentive to researchers, and the remaining $13.3 \%$ thought that research commercialization would improve access to research innovations and extension services. The forty one percent of respondents who said they were not willing to sell their innovations also gave their reasons. The highest percentage of respondents considered low income levels among farmers as a factor that would militate against research commercialization. Similarly, the least percentage of respondents not willing to sell saw research commercialization leading to low adoption of technologies.

Farmers were also willing to pay for innovations from 
Table 2. Definition of Farmers' socio-economic variables.

\begin{tabular}{|c|c|c|c|}
\hline Variable & Definition & Measurement & A Priori expectation \\
\hline$X_{1}$ & Age of the farmer & Years & Positive \\
\hline$X_{2}$ & Educational status & $\begin{array}{l}1 \text { if a respondent had formal education; } 0 \\
\text { otherwise }\end{array}$ & Positive \\
\hline$x_{3}$ & $\begin{array}{l}\text { Total farm income for the } 2013 \text { cropping } \\
\text { season }\end{array}$ & Ghana Cedis $(\mathrm{GHC})$ & positive \\
\hline$X_{4}$ & $\begin{array}{l}\text { Total non-farm income for the } 2013 \\
\text { cropping season }\end{array}$ & Ghana Cedis (GH⿷) & Positive \\
\hline$X_{5}$ & Nativity & $\begin{array}{l}1 \text { if the respondent was a native of the community; } \\
0 \text { if settler farmer }\end{array}$ & Positive \\
\hline$x_{6}$ & Free-rider & $\begin{array}{l}1 \text { if a farmer who could obtain improved seed and } \\
\text { knowledge on agricultural technologies free of } \\
\text { charge from friends and relatives was also willing } \\
\text { to pay; } 0 \text { if a farmer would not pay for innovations } \\
\text { because he could free-ride }\end{array}$ & Negative \\
\hline$x_{7}$ & Number of acres & $\begin{array}{l}\text { Total area of land under cultivation owned by a } \\
\text { respondent in acres. }\end{array}$ & Positive \\
\hline$X_{8}$ & Extension contacts & Number & Positive \\
\hline
\end{tabular}

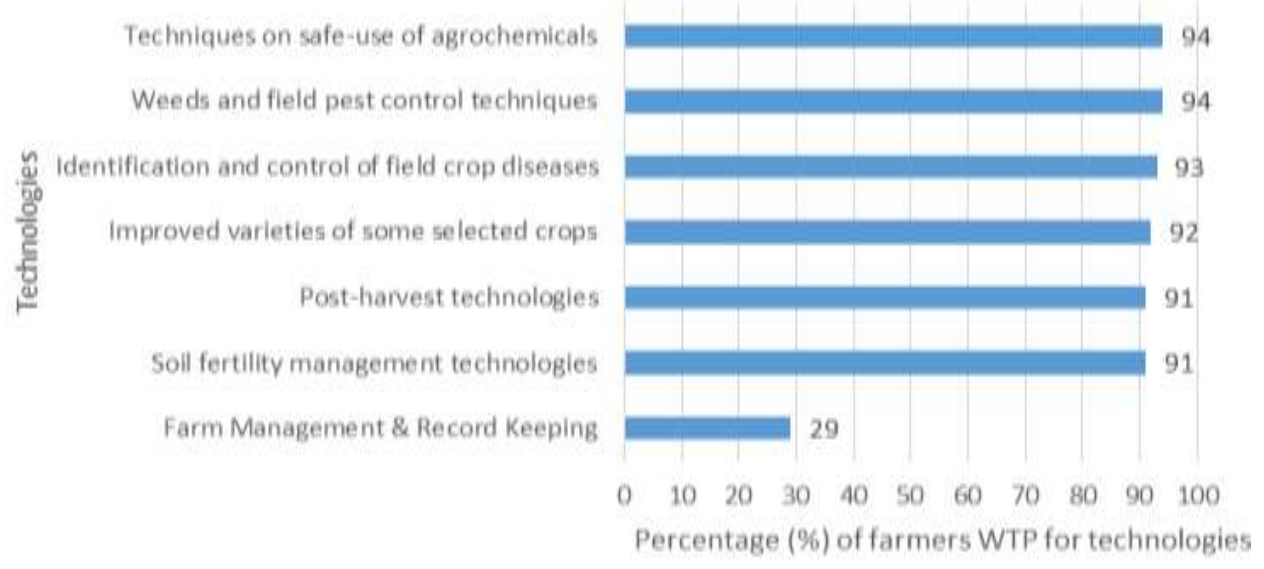

Figure 1. Percentage of farmers willing to pay for Innovations from Agricultural Research

research. On average, $83 \%$ of farmers were willing to pay for all the technologies proposed to them. Figure 1 shows that $94 \%$ of farmers were willing to pay for techniques on safe use of agro-chemicals as well as weeds and field pest control techniques. The technology that farmers were least willing to pay was on training on farm management and record keeping.

Researchers' willingness to accept payments and
farmers' willingness to pay for improved technologies

Contingent valuation was used to solicit monetary values from both researchers and farmers. The rationale behind a WTP study is that it indicates the monetary value that individuals attach to a good or service, which in turn predicts their likely contribution towards the maintenance of the said good or service (Boadu, 1993). Willingness to accept payment (willingness to sell) represents a compensation for the loss of a good or service. In this study, a researcher's willingness to accept payment represents the opportunity cost of extending a research innovation to a farmer.

Table 3 indicates the minimum amounts researchers were willing to accept (Min WTA) as payment for their innovations. From the results, extending innovations to 
Table 3. Farmers' WTP and Researchers' WTA.

\begin{tabular}{lccccccc}
\hline Technologies & $\begin{array}{c}\text { Min WTP } \\
\text { GHC }\end{array}$ & $\begin{array}{c}\text { Max WTP } \\
\text { GHC }\end{array}$ & $\begin{array}{c}\text { Average } \\
\text { WTP GHC }\end{array}$ & $\begin{array}{c}\text { MinWT } \\
\text { A GHC }\end{array}$ & $\begin{array}{c}\text { Max WTA } \\
\text { GHC }\end{array}$ & $\begin{array}{c}\text { Average } \\
\text { WTA GHC }\end{array}$ & $\begin{array}{c}\text { Ratio } \\
\text { WTP:WTA }\end{array}$ \\
\hline $\begin{array}{l}\text { Soil fertility management } \\
\text { technologies }\end{array}$ & 4.00 & 6.00 & 5.00 & 57.00 & 100.00 & 78.50 & $5: 78.5$ \\
$\begin{array}{l}\text { Weeds and field pest control } \\
\text { techniques }\end{array}$ & 4.00 & 6.00 & 5.00 & 53.00 & 100.00 & 76.50 & $5: 76.5$ \\
$\begin{array}{l}\text { Techniques on safe-use of } \\
\text { agro-chemicals }\end{array}$ & 4.00 & 6.00 & 5.00 & 53.00 & 100.00 & 76.50 & $5: 76.5$ \\
$\begin{array}{l}\text { Identification and control of } \\
\text { field crop diseases }\end{array}$ & 4.00 & 6.00 & 5.00 & 50.00 & 100.00 & 75.00 & $5: 75$ \\
$\begin{array}{l}\text { Post-harvest technologies } \\
\begin{array}{l}\text { Farm Management and } \\
\text { record keeping }\end{array}\end{array}$ & 3.00 & 6.00 & 4.50 & 44.00 & 96.00 & 70.00 & $4.5: 70$ \\
\hline
\end{tabular}

The exchange rate at the time of survey was USD1.00 $=\mathrm{GH}$ C2.40.

farmers on record keeping and farm management was the least valued by researchers while that of soil fertility management had the highest value. Researchers were willing to accept $\mathrm{GH} \mathbb{C} 43.00$ and $\mathrm{GH} \mathbb{C 5 7 . 0 0}$, per farmer to provide a day's training on record keeping and farm management techniques as well as soil fertility management techniques, respectively. Below these stated amounts researchers were not willing to sell these techniques. Similarly, researchers would also not be

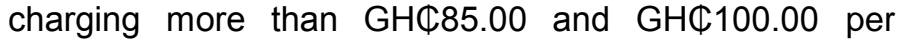
farmer for these two innovations.

The WTA offers in this study are significantly not different from the findings of Kolavalli et al. (2010) that the costs of extension service provided per farmer for the year 2006 were $\mathrm{GH} \$ 52.00$ in the Brong-Ahafo region, GH\$64.00 in the Northern region and GH\$93.00 in the Western region of Ghana. Farmers' willingness to pay for soil fertility management techniques, field crop protection techniques, safe-use of agro-chemicals, post-harvest techniques and farm management and record keeping techniques were also valued. It is important to note that different types of crop technologies have both hardware and software components. An improved crop variety, as a type of hardware technology, cannot be fully exploited without having a complementary set of agronomic practices (Food and Agriculture Organization (FAO, 1997), hence assessing farmers' WTP for these technologies as well as the valuation of these technologies. Table 3 also shows the values farmers offered for these technologies.

Farmers were willing to pay as low as $\mathrm{GH} \nsubseteq 4.00$ each for a day's training on soil fertility management and as high as GHC6.00. They were not willing to pay for a day's training on soil fertility management above GHC6.00.
Respondents were willing to pay as low as $\mathrm{GH} \mathbb{4} 4.00$ and as high as $\mathrm{GH} 66.00$ to receive training on ways of controlling weeds and insect pest on crop fields. Those willing to pay to receive training on safe use of agrochemicals were prepared to pay as low as $\mathrm{GH} \mathbb{4} 4.00$ and as high as GHC6.00, on average to receive the training (Table 3).

The last column of Table 3 highlights the significant wide gap between farmers' willingness to pay for agricultural innovations and researchers' willingness to accept payment for their innovations.

On average, farmers are willing to pay less than $7 \%$ of what researchers are willing to accept for the innovations extended to them. The divergence is as a result of farmers and researchers belonging to two diverging income groups. Researchers are wealthier than the farmers and so WTA will substantially differ from WTP (Hoffman and Spitzer, 1993). The study revealed that on average, the basic monthly salary for a researcher with first degree was $\mathrm{GH} \mathbb{1 4 4 0 . 0 0}$ and that of a non-PhD was GHC1750.00. PhD researchers had a mean basic monthly salary of GHC2380.00. This is in sharp contrast to farmers' mean farm income of GHC968.00.

This finding suggests that research commercialization is an area where subsidies will be required if it is to be successful. The subsidy could be in the form of continuous government subvention to research institutions.

\section{Seed system and farmers' WTP for improved seed}

Improved seed is about the most important technology to the farmer. From Table 4 farmers were willing to pay between $\mathrm{GH}$ 22.00 and $\mathrm{GH} \$ 4.00$ for improved seeds of 
Table 4. Farmers' WTP for improved seed of some selected crops.

\begin{tabular}{lcc}
\hline \multirow{2}{*}{ Crop } & \multicolumn{2}{c}{ Prices offered for $\mathbf{1 ~ K g}$} \\
\cline { 2 - 3 } & Minimum (GHC) & Maximum (GHC) \\
\hline Maize & 2.00 & 4.00 \\
Rice & 2.00 & 3.00 \\
Soya bean & 3.00 & 4.00 \\
Sorghum & 1.00 & 3.00 \\
Tomatoes & 3.00 & 4.00 \\
\hline
\end{tabular}

The exchange rate at the time of survey was USD1.00 $=\mathrm{GH} \$ 2.40$.

Table 5. Marginal effects of the factors influencing researchers' willingness to sell research innovations.

\begin{tabular}{lcc}
\hline Explanatory variables & Marginal effects & STD. error \\
\hline Age & -0.0184289 & $0.00766^{\star *}$ \\
Membership to a professional body & 0.4425909 & $0.17524^{\star *}$ \\
Respondents years of experience & 0.0155304 & 0.03222 \\
Number of publications of a researcher & 0.0669063 & $0.03023^{\star *}$ \\
Non-profit nature of extension delivery & -0.2900798 & 0.19142 \\
Dependence on stated source of salary & 0.1435752 & 0.18466 \\
Necessity to publish in order to be promoted & 0.0788004 & 0.17491 \\
\hline
\end{tabular}

** represent significance level of $5 \%$.

maize, rice and soya bean. At prices above GHđ4.00, farmers were not willing to pay for improved seed. Efforts at promoting the use of hybrid seeds among farmers might not be successful currently, considering the fact that the price of hybrid seed, for example, maize (Panar 53) was $\mathrm{GHC} 10.00$ per $1 \mathrm{Kg}$, far above the maximum stated WTP by the farmers. Efforts should rather be geared towards improving access to the Open Pollinated Varieties (OPVs) whose prices are within the farmers' stated willingness to pay values. Prices of the OPVs ranged from $\mathrm{GH} \mathbb{1} 1.77$ to $\mathrm{GH} \mathbb{2} 2.66$ for maize, rice, soya bean and sorghum for the 2014 cropping season, as reported by the Seed Producers Association of Ghana (SEEDPAG).

\section{Determinants of researchers' willingness to sell innovations}

One of the objectives of the study was to investigate the factors that influenced researchers' willingness to sell the following technologies: improved seed varieties, soil fertility improvement techniques, weed and pest control methods, safe use of agro-chemicals, field crop disease control, post-harvest techniques as well as farm management and record keeping. To do this a probit model was estimated. The significant factors were age, membership to a professional body and number of publications.

The age of researchers had a significant negative influence on willingness to sell research innovations. The marginal effect indicates that an increase in age of a researcher by one year will result in a decrease of the probability of the researcher willing to sell his innovations by $2 \%$. Younger researchers are more commercially oriented because they need to earn more money, besides their salaries in order to have a good start in life. Researchers' membership to a professional body had a positive influence on their willingness to sell their research technologies. Thus, researchers who belonged to professional bodies were more willing to commercialize innovations from research than those who did not belong to any professional body.

Membership to a professional body increases one's network, business orientation and social capital. The positive influence of membership to a professional body on their willingness to commercialize innovations from research was significant at $5 \%$. It is expected that researchers who become members of professional bodies will lead to a higher probability of willingness to sell innovations by $44 \%$. The number of publications by a researcher also had a positive influence on the willingness to commercialize. Thus, as the number of publications by a researcher increases, his willingness to sell research technologies also increases. This was significant at $5 \%$. Furthermore, an increase in the number 
Table 6. MV probit indicating factors influencing farmers' WTP for Innovations.

\begin{tabular}{|c|c|c|c|c|c|c|}
\hline $\begin{array}{l}\text { Explanatory } \\
\text { Variables }\end{array}$ & $\begin{array}{l}\text { Improved } \\
\text { Seed }\end{array}$ & $\begin{array}{c}\text { Soil fertility } \\
\text { improvement } \\
\text { techniques }\end{array}$ & $\begin{array}{c}\text { Weeds and } \\
\text { insect pest } \\
\text { control } \\
\text { methods }\end{array}$ & $\begin{array}{l}\text { Safe use of } \\
\text { agro- } \\
\text { chemicals }\end{array}$ & $\begin{array}{c}\text { Farm } \\
\text { management } \\
\text { and record } \\
\text { keeping }\end{array}$ & $\begin{array}{l}\text { Post-harvest } \\
\text { techniques }\end{array}$ \\
\hline & Coefficient & Coefficient & Coefficient & Coefficient & Coefficient & Coefficient \\
\hline Age & $\begin{array}{c}-0.0222541 \\
(0.0083612)^{\star \star \star}\end{array}$ & $\begin{array}{c}-0.0285107 \\
(0.0081633)^{\star \star \star}\end{array}$ & $\begin{array}{c}-0.0294915 \\
(0.0092794)^{\star \star \star}\end{array}$ & $\begin{array}{c}-0.0487716 \\
(0.0100546)^{\star \star \star}\end{array}$ & $\begin{array}{l}-0.0061457 \\
(0.0060389)\end{array}$ & $\begin{array}{c}-0.0213486 \\
(0.0076276)^{\star \star \star}\end{array}$ \\
\hline Educational status & $\begin{array}{c}0.8566023 \\
(0.4063613)^{* *}\end{array}$ & $\begin{array}{l}-0.0004373 \\
(0.2269114)\end{array}$ & $\begin{array}{l}-0.0898358 \\
(0.2734372)\end{array}$ & $\begin{array}{c}-0.4790022 \\
(0.2654224)^{*}\end{array}$ & $\begin{array}{c}0.430929 \\
(0.1556653)^{\star \star \star}\end{array}$ & $\begin{array}{c}-0.144377 \\
(0.2155912)\end{array}$ \\
\hline Nativity & $\begin{array}{c}0.8973799 \\
(0.2481937)^{\star \star \star}\end{array}$ & $\begin{array}{c}0.7725424 \\
(0.2414772)^{\star *}\end{array}$ & $\begin{array}{c}0.8741929 \\
(0.2820333)^{\star \star \star}\end{array}$ & $\begin{array}{l}0.2542582 \\
(0.313295)\end{array}$ & $\begin{array}{l}-0.0029226 \\
(0.2138322)\end{array}$ & $\begin{array}{c}0.0818802 \\
(0.2621454)\end{array}$ \\
\hline Free-rider & $\begin{array}{c}0.4872093 \\
(0.2353743)^{\star *}\end{array}$ & $\begin{array}{c}0.4128067 \\
(0.2207351)^{*}\end{array}$ & $\begin{array}{c}0.4746116 \\
(0.2559607)^{\star}\end{array}$ & $\begin{array}{c}0.4662275 \\
(0.2736648)\end{array}$ & $\begin{array}{c}0.3498178 \\
(0.1878753)^{*}\end{array}$ & $\begin{array}{c}0.5004964 \\
(0.2112851)^{\star \star}\end{array}$ \\
\hline Number of acres & $\begin{array}{c}0.0130904 \\
(0.0227986)\end{array}$ & $\begin{array}{l}0.0121588 \\
(0.020583)\end{array}$ & $\begin{array}{c}0.0471642 \\
(0.0303452)\end{array}$ & $\begin{array}{c}0.0633813 \\
(0.0348181)^{*}\end{array}$ & $\begin{array}{c}-0.081843 \\
(0.0134122)\end{array}$ & $\begin{array}{c}0.0048097 \\
(0.0175745)\end{array}$ \\
\hline Off-farm income & $\begin{array}{c}0.0130904 \\
(0.0001053)\end{array}$ & $\begin{array}{c}-0.0001431 \\
(0.0000467)^{\star \star \star}\end{array}$ & $\begin{array}{l}-0.0001078 \\
(0.000062)^{\star}\end{array}$ & $\begin{array}{c}9.89 \mathrm{e}-07 \\
(0.0000751)\end{array}$ & $\begin{array}{c}-0.000032 \\
(0.0000453)\end{array}$ & $\begin{array}{l}-0.0000106 \\
(0.0000543)\end{array}$ \\
\hline Farm income & $\begin{array}{c}0.0001169 \\
(0.0001506)\end{array}$ & $\begin{array}{c}0.0000733 \\
(0.0000963)\end{array}$ & $\begin{array}{c}0.0005268 \\
(0.0002579)^{\star \star}\end{array}$ & $\begin{array}{c}0.0005268 \\
(0.0002799)^{*}\end{array}$ & $\begin{array}{c}0.0000625 \\
(0.0000699)\end{array}$ & $\begin{array}{c}-0.000062 \\
(0.0000686)\end{array}$ \\
\hline $\begin{array}{l}\text { Number of contacts } \\
\text { with an A.E.A. }\end{array}$ & $\begin{array}{l}0.0552829 \\
(0.32997)^{*}\end{array}$ & $\begin{array}{l}-0.0308932 \\
(0.0245868)\end{array}$ & $\begin{array}{c}-0.047721 \\
(0.0259496)^{*}\end{array}$ & $\begin{array}{c}-0.0610719 \\
(0.0257548)^{\star *}\end{array}$ & $\begin{array}{c}0.0867617 \\
(0.0174427)^{\star \star \star}\end{array}$ & $\begin{array}{c}0.0043998 \\
(0.0253028)\end{array}$ \\
\hline
\end{tabular}

${ }^{*},{ }^{* *},{ }^{* * *}$, represent $10 \%, 5 \%$ and $1 \%$ levels of significance respectively. NB. Std. Errors are in parenthesis.

of publications by one will increase the probability of a researcher willing to sell innovations by $8 \%$ (Table 5).

\section{Determinants of Farmers' WTP for Research Innovations}

The results from the Multivariate Probit model (MV Probit) looked at farmers' willingness to pay for the following technologies: improved seed varieties, soil fertility improvement techniques, weed and pest control methods, safe use of agro-chemicals, field crop diseases control, post-harvest techniques and farm management and record keeping. The log likelihood and Wald chi-square values were -550 and 143.44 , respectively. The Wald chisquare value was significant at $1 \%$, suggesting that all the explanatory variables jointly determined the dependent variable. The endogeneity within the data set, as evidenced by the positive correlations between willingness to pay for the various technologies was corrected using Geweke-Hajivassiliou-Kean (GHK) smooth recursive conditioning simulator (Kankwamba et al.
2012).

Across all the technologies, age of the respondents had a significant negative influence on their willingness to pay for agricultural technologies. This means that as farmers grow older, the probability of their willingness to pay for agricultural innovations decreases. Possibly, older farmers would not like to go through the mental stress associated with learning agricultural technologies and may also be risk averse. Mwaura et al. (2010) found that increasing age of respondents was associated with reducing likelihood for their willingness to pay for agricultural innovations. To Kaliba et al. (1997), young people have relatively high disposable income, are less risk averse, exposed to a wide range of information channels and have the potential to be more educated.

Except for farmers' willingness to pay for crop diseases control and farm management and record keeping, the age variable was significant at $1 \%$ significant level for WTP for the other techniques. From Table 6, for every additional year above the mean, the probability to pay for improved seed, soil fertility improvement techniques, weed and pest control methods, safe-use of agro- 
chemicals and post-harvest techniques decreases by $0.022541, \quad 0.0285107,0.0294915,0.0487716$ and 0.0213486 , respectively, holding all other variables constant. The educational status of the farmer significantly and positively influenced his/ her WTP for improved seed and knowledge on farm management and record keeping at significance levels of $5 \%$ and $1 \%$ respectively. Educational status was however found to have a negative influence on farmers ' WTP for safe-use of agro-chemicals techniques at significance level of $10 \%$. Thus farmers who had at least basic education were less willing to pay for training on safe use of agro-chemicals. Farmers with formal education felt they could on their own understand issues regarding safe use of agro-chemicals and did not have to pay to receive additional information.

Nativity significantly and positively affected farmers' WTP for improved seed, soil fertility improvement techniques as well as field crop protection techniques. The nativity variable was significant at $1 \%$ for farmers' WTP for improved seed, soil fertility improvement techniques and field crop protection techniques. Thus farmers who were natives were more willing to pay for these innovations as against settler farmers.

The issue of free-rider is often considered as one of the possible limitations to commercializing innovations from agricultural research. In ascertaining the influence of freeriding on willingness to pay, respondents were asked whether they were still willing to pay for the proposed package of research technologies should they have free access to the same package from family members and friends. From the estimation, the free-rider variable had significant and a positive influence on farmers' WTP for improved seed, soil fertility improvement techniques, field crop protection, post-harvest techniques, farm management and record keeping techniques as well as techniques on safe use of agro-chemicals. This implies that issue of free-riding exists in the provision of agricultural services, just as any public good, but contrary to our a priori expectations it will increase farmers 'WTP for agricultural innovations.

The free-rider variable was significant at significance levels of $5 \%$ for WTP for improved seed and post-harvest techniques, and $10 \%$ for WTP for soil fertility improvement techniques, weed and pest control methods and knowledge on safe use of agro-chemicals. For example, from Table 6, a farmer who had free advice from a friend on post-harvest techniques, his probability of willing to pay for innovations on post-harvest technology in future will increase by 0.50 or $50 \%$. The number of acreages a farmer cultivated for the 2013 cropping season had no significant influence on WTP for all the technologies, except for safe use of agro-chemicals. Thus, farmers who had more area of land under cultivation were more willing to pay for training on safe use of agro-chemicals. This was at $10 \%$ significance level. The previous off-farm income was found to have a negative influence on farmers' WTP for both soil fertility improvement techniques and field crop protection techniques. The previous farm income had a significant and positive effect on farmers' willingness to pay for weeds and pest control techniques as well as safe-use of agro-chemicals.

It was also important to determine whether the number of contacts (field visits) a respondent had with an Agricultural Extension Agent (A.E.A.) had any influence on willingness to pay for the technologies. The results suggests a positive influence on the respondent's WTP for farm management and record keeping techniques and improved seed at significance levels of $1 \%$ and $10 \%$ respectively. However, farmers who had more visits from A.E.As were found to be less willing to pay for weed and pest control methods and safe use of agro-chemicals. If the number of contacts a farmer had with an extension agent can be used as proxy for measuring prior access to agricultural services, then this finding supports that of Ulimwengu and Sanyal (2011) whose results suggest that prior access to agricultural services tends to reduce farmers ' willingness to pay. The effects of the explanatory variables on farmers' WTP for innovations on crop diseases identification and control measures were not significant, hence not shown in Table 6 . This is however shown in Appendix 1.

\section{CONCLUSIONS AND RECOMMENDATIONS}

The objective of this study was to investigate researchers' willing to sell their innovations as well as farmers willingness to pay for such research findings. Generally, farmers were willing to pay for innovations from research in the same way that a number of researchers were willing to sell their innovations. Farmers in the study attached the same value to all the technologies proposed to them. On the whole, farmers were willing to pay a

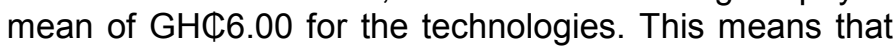
farmers give equal importance to research innovations irrespective of whether it is a post-harvest technique or soil fertility management technique. Among the researchers, there were different valuations for the technologies. Soil fertility management technologies had the highest mean minimum WTA (GHC57.00) and farm management and record keeping techniques was least valued (GH\$43.00). Government's subvention to research institutions should also be continued during research commercialization. This will serve as $s$ subsidy for research commercialization

The success of research commercialization will be dependent on improvement in both farm and non-farm incomes, increase in land area under cultivation and improvement in the educational status of farmers. Also, on the part of researchers, increase in the number of publications of researchers, encouraging the youth in academia to go into research and scientists becoming members of professional bodies would enhance research commercialization. In conclusion, research commercialization is possible but cannot be an alternative to public funding of research judging from the low WTP 
valuations from farmers. Government can go ahead and implement the policy on research commercialization with two expectations; one is that the monetary returns would be low; and the other is that at least research commercialization would serve as another source of revenue for further research. The wide disparity between WTP and WTA means that commercialization of research could not be run on full cost-recovery. Government should therefore set up a statutory fund dedicated to agricultural research. Researchers should consider the issue of patenting their innovations very seriously, as it is one of the means through which they could get financial reward for their hard work and would be seen as being entrepreneurial. Also researchers should develop entrepreneurial and marketing skills. This is key to reducing the gap between WTA and WTP. Researchers should be encouraged to form and belong to professional bodies as it had a significant and positive influence on willingness to sell innovations from research. Research institutions should continue to use the number of publications of a researcher as requirement for promotions. These institutions could also consider whether a researcher has a patent right as additional requirement for promotions.

\section{Conflicts of interest}

The authors have not declared any conflict of interests.

\section{REFERENCES}

Ali S, Ahmed M, Ali T, Islam D, Iqbal MZ (2008). Farmers' Willingness to Pay (WTP) for Advisory Services by Private Sector Extension: the case of Punjab. Pak. J. Agric. Sci. 4(3).

Bandaryan R (2009). Marketing and Commercializing modern technologies: Processes, Key and Simplifying Factors of Success. Dev. Technol. 19:39-45

Bechdol AE (2012). Food and Agriculture Innovation; $21^{\text {st }}$ Century Opportunities for Indiana. BioCrossroads. Available at http://www.biocrossroads.com/wp-content/uploads/2014/09/FoodAgricultural (Accessed on $1^{\text {st }}$ December, 2014)

Boadu FO (1993). Contingent Valuation for household water in rural Ghana. J. Eco.43(3):458-65.

Borsch-Supan A, Hajivassiliou V (1993). Smooth unbiased multivariate probability simulators for maximum likelihood estimation of limited dependent variable models. J. Eco.58:347-368.

Cappellari L, Jenkins SP (2003). Multivariate probit regression using simulated maximum likelihood. Stata J. 3(3):278-294.

Carmona-Torres M, Calatrava-Requena $\mathrm{J}$ (2006). Bid design and its influence on the stated willingness to pay in a Contingent valuation study. Contributed paper for presentation at the International Association of Agricultural Economists Conference, Gold Coast, Australia, August 12-18, 2006

Colman D, Young T (1989). Principles of Agricultural Economics: Markets and Prices in less developed Countries. Cambridge University Press, Cambridge.

Fakur B (2007). Preparing the Ground for the Development of Commercializing Research Results at Universities. Rahyaft 40:46-54.

Gujarati DN (2004). Essentials of Econometrics $3^{\text {rd }}$ Edition. McGraw-Hill International Edition.
Gurel A (1998). A Study on the Factors Affecting the Behaviours of Sunflower Producers to Technology Innovations in Malkara District. Trakya University Tekirdag Faculty of Agric., Publication No. 262, Res. No. 90, Tekirdag.

Hoffman E, Spitzer ML (1993). Willingness to Pay vs. Willingness to Accept: Legal and Economic Implications, 71 WASH. U.L. Q.59. available http://openscolarship.wustl.edu/law_lawreview/vol71/iss1/2 (Accessed on $10^{\text {th }}$ April, 2015)

Holden ST, Shiferaw B (2002). Poverty and Land Degradation: Peasant's Willingness to Pay to Sustain Land Productivity. In: Barrett CB, Place FM, Aboud AA (Eds) Natural Resource Management Practices: Improving Sustainable Agricultural Production in SubSaharan Africa, pp. 91-102. CABI Publishing: New York.

Kaliba AR, Featherstone AM, Norman, DW (1997). A Stall-feeding management for improved cattle in semiarid central Tanzania: factors influencing adoption. Agric. Econ. 17:133-146

Karlsson M (2004). Commercialization of Research Results in the United States: An Overview of Federal Academic Technology Transfer. Swedish Institute for Growth Policy Studies, Washington, DC. pp. $35-45$

Keane MP (1994). A computationally practical simulation estimator for panel data. Econometrica 62:95-116

Kolavalli S, Birner R, Benin S, Horowitz L, Babu S, Asenso-Okyere K, Thompson NM, Poku J (2010). Institutional and Public Expenditure Review of Ghana's Ministry of Food and Agriculture. IFPRI Discussion Paper 01020.

Markmann G, Siegel D, Wright M (2008). Research and technology commercialization. J. Management Studies 45: 1401-1423.

Mohammadi M, Esmailzadeh H, Dehnavieh R (2009). Commercializing research: Challenges and Solutions. Tehran: The National Centre of Medical Researches.

Mwaura F, Muwanika FR, Okoboi G (2010). Willingness to pay for extension services in Uganda among farmers involved in crop and animal husbandry. Contributed Paper presented at the Joint $3^{\text {rd }}$ African Association of Agricultural Economists (AAAE) and $48^{\text {th }}$ Agricultural Economists Association of South Africa (AEASA) Conference, Cape Town, South Africa, September 19-23, 2010.

Nemati M, Jamshidi L (2007). Investigation of the Relationship and Effect of the Process of sharing Knowledge and Experience on the Development of Social Capital among of Technological Units and Development Centre in Shahidbeheshti University, Iran. Proceeding of the $1^{\text {st }}$ National on Knowledge Management, Razi International Congress Centre, pp. 2-16.

Perkmann M, Tartari V, Mckelvey M, Autio E, Broström A, D'Este P, Fini R, Geuna A, Grimaldi R, Hughes A, Krabel S, Kitson M, Llerena P, Lissoni F, Salter A, Sobrero M (2013). Academic engagement and commercialization: A review of the literature on university-industry relations. Research Policy 42:423-442.

Radfar R, Khamseh A, Madani H (2009). Commercializing Technology as an Effective Factor on the Development of Technology and Economy. Roshd, 20:23-40.

Rogers EM (1995). Diffusion of Innovations. New York: The Free Press.

Salter AJ, Martin BR (2001). The Economic Benefits of Publicly Funded Basic Research: A Critical Review. Research Policy 30: 509-532.

Tripp R, Mensah-Bonsu (2013). Ghana's Commercial Seed Sector: New Incentives or Continued Complacency? International Food Policy Research Institute (IFPRI). Working Paper 32.

Ulimwengu J, Sanyal P (2011). Joint Estimation of Farmers' Stated Willingness to pay for Agricultural Services. IFPRI Discussion Paper 01070. 
Appendix 1. Multivariate probit indicating factors influencing farmers' WTP for innovations.

\begin{tabular}{|c|c|c|c|c|c|c|c|}
\hline \multirow[t]{2}{*}{ Explanatory Variables } & Improved seed & $\begin{array}{c}\text { Soil fertility improvement } \\
\text { techniques }\end{array}$ & $\begin{array}{l}\text { Weeds and insect pest } \\
\text { control methods }\end{array}$ & $\begin{array}{l}\text { Safe use of agro- } \\
\text { chemicals }\end{array}$ & $\begin{array}{c}\text { Crop diseases } \\
\text { identification and control } \\
\text { measures }\end{array}$ & $\begin{array}{l}\text { Farm management and record } \\
\text { keeping }\end{array}$ & $\begin{array}{l}\text { Post-harvest } \\
\text { techniques }\end{array}$ \\
\hline & Coefficient & Coefficient & Coefficient & Coefficient & Coefficient & Coefficient & Coefficient \\
\hline \multirow{2}{*}{$\begin{array}{r}\text { Age } \\
\text { Educational status }\end{array}$} & $\begin{array}{c}-0.0222541 \\
(0.0083612)^{\star \star \star}\end{array}$ & $\begin{array}{c}-0.0285107 \\
(0.0081633)^{\star \star \star}\end{array}$ & $\begin{array}{c}-0.0294915 \\
(0.0092794)^{\star \star *}\end{array}$ & $\begin{array}{c}-0.0487716 \\
(0.0100546)^{\star \star \star}\end{array}$ & $\begin{array}{c}-0.003401 \\
(0.0085466)\end{array}$ & $\begin{array}{l}-0.0061457 \\
(0.0060389)\end{array}$ & $\begin{array}{l}-0.0213486 \\
(0.007623)^{\star \star \star}\end{array}$ \\
\hline & $\begin{array}{c}0.8566023 \\
(0.4063613)^{* *}\end{array}$ & $\begin{array}{l}-0.0004373 \\
(0.2269114)\end{array}$ & $\begin{array}{l}-0.0898358 \\
(0.2734372)\end{array}$ & $\begin{array}{l}-0.4790022 \\
(0.2654224)^{\star}\end{array}$ & $\begin{array}{l}-0.0351378 \\
(0.2238314)\end{array}$ & $\begin{array}{c}0.430929 \\
(0.1556653)^{\star \star \star}\end{array}$ & $\begin{array}{l}-0.144377 \\
(0.2155912)\end{array}$ \\
\hline Nativity & $\begin{array}{c}0.8973799 \\
(0.2481937)^{* * *}\end{array}$ & $\begin{array}{c}0.7725424 \\
(0.2414772)^{* *}\end{array}$ & $\begin{array}{c}0.8741929 \\
(0.2820333)^{* * *}\end{array}$ & $\begin{array}{l}0.2542582 \\
(0.313295)\end{array}$ & $\begin{array}{l}-0.4626531 \\
(0.342405)\end{array}$ & $\begin{array}{l}-0.0029226 \\
(0.2138322)\end{array}$ & $\begin{array}{c}0.0818802 \\
(0.2621454)\end{array}$ \\
\hline Free-rider & $\begin{array}{c}0.4872093 \\
(0.2353743)^{\star \star}\end{array}$ & $\begin{array}{c}0.4128067 \\
(0.2207351)^{*}\end{array}$ & $\begin{array}{c}0.4746116 \\
(0.2559607)^{*}\end{array}$ & $\begin{array}{l}0.4662275 \\
(0.2736648)\end{array}$ & $\begin{array}{l}0.2228686 \\
(0.2347527)\end{array}$ & $\begin{array}{c}0.3498178 \\
(0.1878753)^{*}\end{array}$ & $\begin{array}{c}0.5004964 \\
(0.211285)^{\star *}\end{array}$ \\
\hline Number of acres & $\begin{array}{c}0.0130904 \\
(0.0227986)\end{array}$ & $\begin{array}{l}0.0121588 \\
(0.020583)\end{array}$ & $\begin{array}{c}0.0471642 \\
(0.0303452)\end{array}$ & $\begin{array}{c}0.0633813 \\
(0.0348181)^{*}\end{array}$ & $\begin{array}{c}0.0264265 \\
(0.0225748)\end{array}$ & $\begin{array}{l}-0.081843 \\
(0.0134122)\end{array}$ & $\begin{array}{c}0.0048097 \\
(0.0175745)\end{array}$ \\
\hline Off-Farm income & $\begin{array}{l}0.0130904 \\
(0.0001053)\end{array}$ & $\begin{array}{c}-0.0001431 \\
(0.0000467)^{* * *}\end{array}$ & $\begin{array}{l}-0.0001078 \\
(0.000062)^{*}\end{array}$ & $\begin{array}{c}9.89 \mathrm{e}-07 \\
(0.0000751)\end{array}$ & $\begin{array}{l}-0.0000177 \\
(0.0000666)\end{array}$ & $\begin{array}{l}-0.000032 \\
(0.0000453)\end{array}$ & $\begin{array}{l}-0.0000106 \\
(0.0000543)\end{array}$ \\
\hline Farm income & $\begin{array}{c}0.0001169 \\
(0.0001506)\end{array}$ & $\begin{array}{c}0.0000733 \\
(0.0000963)\end{array}$ & $\begin{array}{c}0.0005268 \\
(0.0002579)^{\star *}\end{array}$ & $\begin{array}{c}0.0005268 \\
(0.0002799)^{*}\end{array}$ & $\begin{array}{c}0.0000717 \\
(0.0001585)\end{array}$ & $\begin{array}{c}0.0000625 \\
(0.0000699)\end{array}$ & $\begin{array}{c}-0.000062 \\
(0.0000686)\end{array}$ \\
\hline Contacts with an A.E.A. & $\begin{array}{l}0.0552829 \\
(0.32997)^{*}\end{array}$ & $\begin{array}{l}-0.0308932 \\
(0.0245868)\end{array}$ & $\begin{array}{c}-0.047721 \\
(0.0259496)^{*}\end{array}$ & $\begin{array}{c}-0.0610719 \\
(0.0257548)^{* *}\end{array}$ & $\begin{array}{l}-0.0208771 \\
(0.0251704)\end{array}$ & $\begin{array}{c}0.0867617 \\
(0.0174427)^{\star \star \star}\end{array}$ & $\begin{array}{c}0.0043998 \\
(0.0253028)\end{array}$ \\
\hline
\end{tabular}

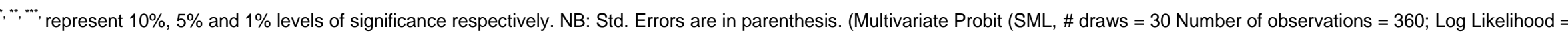
-550.02745 ; Wald chi-square $=143.44 ;$ Prob $>$ chi-square $(0.000)$. 